Yüzüncü Y1l Üniversitesi
Tarim Bilimleri Dergisi

Araştırma Makalesi (Research Article)

\title{
Yapră̆ı Yenen Sebzelerdeki Mikroorganizma Türlerinin MALDI-TOF MS (Matris Destekli Lazer Desorpsiyon/İyonizasyon Uçuş Süresi Kütle Spektrometresi) Tekniği Kullanılarak Tanılanması
}

\author{
Aysun UYSAL ${ }^{* 1,2}$, Şener KURT ${ }^{1,2}$, Soner SOYLU ${ }^{1}$, E. Mine SOYLU ${ }^{1,2}$, Merve KARA $^{1}$ \\ ${ }^{1}$ Hatay Mustafa Kemal Üniversitesi, Ziraat Fakültesi, Bitki Koruma Bölümü, 31060, Hatay, Türkiye \\ ${ }^{2}$ Hatay Mustafa Kemal Üniversitesi, Bitki Sağlığ Kliniği Uygulama ve Araştırma Merkezi, 31060, Hatay, \\ Türkiye \\ *Sorumlu yazar e-posta: aysunuysal31@gmail.com, aysunuysal48@windowslive.com
}

\section{Makale Bilgileri}

Geliş: 01.10.2019

Kabul: 15.11.2019

Online Yayınlanma 31.12.2019

DOI: $10.29133 /$ yyutbd.627850

\section{Anahtar kelimeler} MALDI-TOF MS,

Mikroorganizma,

Taze sebze,

Tanı
Öz: Gıda kaynaklı fungal ve bakteriyel patojenler giderek taze meyve ve sebzelerle ilişkilendirilmektedir. Taze üretilen bitkilerin bakteriyel kolonizasyonu, diş dokuda yüksek seviyelerde oluşabilir, ancak bitki dokusu içerisinde bakteriler de tespit edilmektedir. Hatay ilinin Defne ve Antakya ilçelerinde farklı sebze pazarlarından marul, 1spanak, lahana, roka, nane, maydanoz, dereotu, pırasa gibi yapraklı sebzeler toplanmıştır. Mikrobiyolojik analizler için patates dekstroz agar, nutrient agar ve kanlı agar besi yerleri kullanılmıştır. $\mathrm{Bu}$ mikroorganizmaların tanılanması, fenotipik karakterler ve matris destekli lazer desorpsiyon/iyonizasyon uçuş süresi kütle spektrometresi (MALDI-TOF MS) tekniğine dayalı olarak gerçekleştirilmiştir. MALDI-TOF MS analizi sonucuna göre mikroorganizmaların dağılımı incelendiğinde, tür düzeyinde 60 adet ile en fazla bakteri türleri tanılanırken, bunu 4 adet fungus ve 1 adet maya izlemiștir. En fazla mikroorganizma türü marul örneklerinden elde edilmiștir. Cins düzeyinde dağılımları incelendiğinde; 9 tür ile Pseudomonas başta gelirken, bunu 5 tür ile Lactobacillus, 4 tür ile Acinetobacter ve 2 tür ile Klebsiella, Citrobacter, Enterobacter, Lysinibacillus, Pantoea 1 tür Bacillus, 1 tür Escherichia coli, 1 tür Exiguobacterium cinsleri izlemiştir. Mikroorganizma türlerinin koloni yoğunlukları incelendiğinde, en yoğun koloni Pseudomonas ve Acinetobacter cinsine ait türlerde belirlenmiştir. En az koloni yoğunluğu funguslarda gözlenmiştir. Çalışma sonucunda Salmonella sp, Klebsiella pneumoniae, Escherichia coli, Bacillus cereus, Klebsiella oxytoca türleri insan sağlı̆̆ için en tehlikeli türler olarak bulunmuştur.

\section{Identification of Microorganism Species in Leafy Vegetables Using MALDI-TOF MS (Matrix Assisted Laser Desorption / Ionization Mass Spectrometry) Technique}

\section{Article Info}

Received: 01.10 .2019

Accepted: 15.11 .2019

Online Published 31.12.2019

DOI: $10.29133 /$ yyutbd.627850

Keywords

MALDI-TOF MS,

Microorganism,

fresh vegetables,

identification,
Abstract: The foodborne fungal and bacterial pathogens are increasingly associated with fresh fruit and vegetables. Bacterial colonization of fresh produce plants can occur to high levels on the external tissue but bacteria are detected within plant tissue. Leafy vegetables such as lettuce, spinach, cabbage, rocket, mint, parsley, dill, and leek were collected from different vegetable markets in the counties of Defne and Antakya of Hatay province. Growing media potato dextrose agar, nutrient agar and blood agar media were used for microbiological analysis. Their identification were performed based on phenotypic characters and matrix-assisted laser desorption/ionization time-offlight mass spectrometry (MALDI-TOF MS) technique. According to the results 
of MALDI-TOF MS analysis, when the distribution of microorganisms was examined, the most common bacterial species were identified with 60 species at the species level, followed by 4 fungi and 1 yeast. The most common microorganism species were obtained from lettuce samples. When the distribution of species level is examined; firstly, 9 species with Pseudomonas, 5 species with Lactobacillus, 4 species with Acinetobacter and 2 species with Klebsiella, Citrobacter, Enterobacter, Lysinibacillus were obtained and Pantoea one species Bacillus, one species Escherichia coli, one species followed by Exiguobacterium genera. When the colony density of microorganism species was examined, the most intensive colony was determined in the species belonging to the genus Pseudomonas and Acinetobacter. At least colony density was observed in fungi. In result, Salmonella sp, Klebsiella pneumoniae, Escherichia coli, Bacillus cereus, Klebsiella oxytoca species were found to be very dangerous species for human health.

\section{Giriş}

Tüketim kolaylığı nedeniyle taze sebzelerin insan beslenmesinde önemli rol oynadığı bilinmektedir. Ayrıca bu tip ürünler işlem görmemesi nedeniyle besin değerleri açısından da oldukça rağbet görmektedir. Genel olarak dış görünüşüne bakılarak satın alınan taze sebze hasat edildikten sonra çeşitli etkenlerle değişikliğe uğradığından duyusal ve beslenme kalitelerinde düşüş görülmektedir. $\mathrm{Bu}$ etkenler arasında en önemlisi mikroorganizmaların türü ve yoğunluğudur. $\mathrm{Bu}$ şekilde, mikroorganizmalar kimyasal ve fiziksel kaliteyi de etkileyerek taze sebze ve meyvelerin yenilemez hal almasına neden olmaktadırlar. Pseudomonas, Erwinia, Xanthomonas, Flovabacterium Alcaligenes, Acinetobacter, Leuconostoc, Lactobacillus Enterobacter, Micrococcus, Serratia ve Streptococcus, Salmonella, Shigella, Escherichia coli, Yersinia, Listeria doğal mikroflorayı oluşturan bakterilerdir. Cryptococcus, Candida, Rhodotorula ve Sporobolomyces sebzelerde tanımlanan maya cinslerini ve Cladosporium, Aureobasidium, Aspergillus, Penicillium, Phoma, Botrytis, Fusarium, Epicoccum ve Geotrichum mikrofloradaki küfleri oluşturur (Roberts ve ark., 1998; Lund ve ark., 2000).

Sebzeler, beslenmeyi ve sağlığa yararlarını azaltan çok çeşitli mikroorganizmaları barındırır, böylece taze veya az işlenmiş sebzelerin tüketimi ile ilişkili insan enfeksiyonlarının yaygınlığı artar. Taze sebze tüketimiyle ilişkili gıda kaynaklı hastalıkların salgınları, taze ürün talebindeki artışa bağlı olarak artmıştır. Bu sebzelerin Salmonella sp, Shigella sp, E. coli O157: H7, Listeria monocytogenes ve Campylobacter sp. dahil olmak üzere çeşitli bakteriyel patojenlerle tarladan tüketime kadar çeşitli noktalardan herhangi bir şekilde bulaşabilmektedir (Beuchat, 2002; Sengun ve ark., 2004; Vandekinderen ve ark.,2008). Bu etkenlerden bazıları, gıda arzının küreselleşmesi, ithalat yoluyla patojenlerin yeni coğrafi alanlara girişi, arıtılmış atık su, bitkisel üretim için gübreleme, sulama ve çeşitli tarımsal uygulamalar ve hasat sonrası uygulanan işleme teknikleridir. Çoğu sebze işleyicisi ve tüketicisi, taze sebzeleri yıkamanın yüzeylerindeki mikrobiyal yükü azaltacağını varsaymakla birlikte, çalışmalar, suyun tek başına yıkamanın taze sebzelerde mikrobiyal popülasyonu azaltmada etkili olmadığı (Ayhan ve ark., 2011), buna karşılık UV-C $\left(2.83 \mathrm{~kJ} / \mathrm{m}^{2}\right)$ radyasyon uygulamalarının mikrobiyal enfeksiyonları engellemede etkili olduğu gösterilmiş̧ir (Kasım ve Kasım, 2016).

İnsanların tüketimine yönelik bitkilerin mikrobiyal kontaminasyonu, gıda güvenliği ve insan sağlığ 1 için artan bir endişe kaynağını oluşturmaktadır. 1996 yılı gıda güvenliği için öncü bir yıl olmuştur. Escherichia coli O157: H7 (EcO157: H7), çoğunlukla okul çağındaki çocuklardan oluşan 10.000 kişiden fazla insanın hastalığa yakalanmasına neden olmuştur. 2011 yılında Hamburg'da Escherichia coli (EHEC) O104: H4 ile kontamine olan ürünlerin tüketimi ile ilgili 2011 salgınları, bitkilerle ilişkili büyük çaplı hastalık salgınlarının örneklerinden sadece biridir (Mellmann ve ark. 2011). Yıllık halk sağlığı salgınları konusunda yapılan çalışmalar, son yıllarda hastalık salgınlarının hem sayı ve hem de boyutlarının arttığını ortaya koymuştur (Sivapalasingam ve ark., 2004). Bu salgınların sıklıkla tespit edildiği ürünler, hepsi minimal işlemden geçirilerek tüketilen yapraklı yeşil bitkiler, kavunlar, filizler, üzümsü meyveler, domates ve yeşil soğan bitkileridir. 
İnsan patojeni bakteriler arasında yer alan Enterococci, Serratia, Enterobacter ve Salmonella, bitkilerde hastalığa neden olma eğilimi oldukça yüksektir (Hasnain ve ark., 2015). Stenotrophomonas'ın (Sharma ve ark., 2014), Burkholderia ve Pantoea'nın farklı bitki patojeni türleri insan patojenleri olarak gelişmektedir (Kirzinger ve ark., 2011). Bazı bitki endofitleri, sözgelimi Cryptococcus gattii (Sharma ve ark., 2014), Streptomyces türleri, Klebsiella pneumonia, Morganella morganii ve Pantoea agglomerans bitkilerde çoğunlukla belirti oluşturmazlar, ancak klinik anlamda önem taşımaktadırlar (Kirzinger ve ark., 2011). Rhizopus arrhizus, Alternaria alternata, Fusarium oxysporum, Aspergillus flavus ve Microascus cinereus, insanları enfekte etmek üzere değişikliğe uğramış fungal bitki patojenleridir (Sharma ve ark., 2014). Bazı patojenlerin patojenisitelerini belirleyen faktörler, hem bitkiler hem de insanlar için bilinirken, diğerleri ya bilinmemekte ya da sadece tek bir konukçu durumunda tanımlanmaktadır. Kirzinger ve ark. (2011), hastalığa neden olan faktörlerin yanı sıra birçok çapraz hastalığın (hem bitkiler hem de insanlar) birçok enfeksiyon hedef alanını aydınlatmışlardır.

Gıda ve çevre endüstrisi, tıp ve tarım gibi alanlarda halk sağlığını tehdit eden mikroorganizmaların saptanması ve miktarlarının belirlenmesi konusunda yeni ve güncel moleküler tekniklerin geliştirilmesi önemlidir (Taşkın, 2017). Kütle spektrometresinin (MS) keşfinden bu yana mikroorganizmalar için, hücre yüzey proteinlerinin profillemesine dayanan çok sayıda tanımlama yöntemi gerçekleştirilmiştir. Bunlardan birisi olan Matris yardımlı lazer desorpsiyon/iyonizasyon uçuş süresi kütle spektrometresi (MALDI-TOF MS), tüm hücre analizini esas alarak mikroorganizmaların protein parmak izine dayanarak hizlı tanımlanması, tiplendirilmesi ve sinıflandırılması alanında umut verici uygulamalara sahip en güvenilir araçlardan birisi olarak ortaya çıkmıştır. Günümüzde, ticari MALDI sistemleri, biyolojik araştırma çalışmaları için olduğu gibi, klinik tıpta, biyoteknoloji ve endüstride tanısal uygulamalar için de erişilebilir durumdadır (Carolis ve ark., 2012; Chalupová, ve ark., 2014). Aspergillus, Fusarium, Penicillium veya Trichoderma gibi birçok fungal cins üyeleri ve aynı zamanda klinik örneklerden çeşitli mayalar (örn., Candida albicans) MALDI-TOF MS tarafından başarıyla tanımlanabilmiştir. Bu cihaz, çoğunlukla protein seviyesinde ribozomal proteinleri tespit edebilmektedir.

Ülkemizde ve dünyada yapılan çalışmalarda da görüleceği gibi yaprağı yenen sebzelerde önemli derecede mikrobiyolojik sorunların olduğu bilinmektedir. Bununla birlikte bu tespit edilen mikrobiyolojik sorunların, ne tür etmenler tarafından oluşturulduğunu belirlemek büyük önem arz etmektedir. Bu mikrobiyolojik türlerin teşhisinin hızlı, ucuz ve güvenilir bir şekilde gerçekleştirilmesi, sorunların çözümü noktasında en önemli aşamayı oluşturmaktadır. Artık günümüzde analiz çalışmalarında kullanılan son teknolojik cihazlar, tanı ve teşhiste son derece önemlidir. Üniversitemizde kurulan Bitki Sağlığı Kliniği Uygulama ve Araştırma Merkezi bünyesinde bulunan son derece hızlı, teknolojik ve güvenilir bir cihaz olan MALDI TOF MS (Matrix asisted laser desorption ionization- time of flight mass spectrometry) ile mikrobiyal analizlerin yapılmas1, hem bilimsel hem de uygulamaya yönelik olarak önemli sonuçlar ortaya koymuştur.

$\mathrm{Bu}$ çalışma, Hatay iline farklı sebze satış yerlerinden alınan bazı yaprağı yenen sebze türlerinin (marul, ıspanak, lahana, roka, nane, maydanoz, dereotu, pırasa) iç ve dış dokularından elde edilen mikroorganizmaların fenotipik karakterler ve MALDI-TOF MS tekniğini kullanarak tanımlamak amacıyla gerçekleştirilmiştir.

\section{Materyal ve Yöntem}

Araştırma, Hatay ilinin Antakya ve Defne ilçelerinde 2018 yılının farklı aylarında, marul, ıspanak, lahana, roka, nane, maydanoz, dereotu ve pırasa gibi yaprağ 1 yenen sebzelerin satışa sunulduğu semt pazarı, manav ve sebze satış reyonu bulunan marketlerde inceleme, gözlemler ve analizler sonucu yapılmıştır. Materyal olarak, marul, 1spanak, maydanoz, dereotu, nane, roka, lahana, pazı, pırasa sebzeleri kullanılmıştır. Yaprağı yenen sebzelerdeki mikroorganizma türlerini tespit etmek için örneklemeler yapılmıştır.

\section{1. Örneklerin toplanması}

Hatay ilinin Antakya ve Defne ilçelerinde 2018 yılının farklı aylarında (ocak-nisan ve ekim aralık) marul, 1spanak, lahana, roka, nane, maydanoz, dereotu ve pırasa gibi yaprağı yenen sebzelerin 
satışa sunulduğu semt pazarı, manav ve sebze satış reyonu bulunan marketlerde inceleme ve gözlemler yapılmıştır. Semt pazarlarında, ürün çeşitliliği bol olan en az 5 pazarcı tezgâhı belirlenerek bu tezgâhlardan örnek alımları yapılmıştır. Örnek alma yöntemi, tesadüfi örnekleme yöntemine göre yapılmıştır. Farklı tür ve çeşitlere ait, temiz, tüketime hazır olarak sunulan bitki örnekleri alınıp plastik torbalara konulmuş ve üzerine, her bir örnek için alınan yer, bitki türü kaydedilmiştir. Alınan tüm örnekler, bozulmayacak şekilde soğutucu içerisinde analiz için laboratuvara transfer edilmiştir.

\subsection{Mikroorganizma türlerinin izolasyonu}

Laboratuvara getirilen sebze örnekleri, önce $100 \mathrm{ml}$ tuzlu su (saline buffer) ve sonra $100 \mathrm{ml}$ steril su ile farklı steril kaplarda yıkanmıştır. $10^{-1}$ ve $10^{-2}$ seyreltme seviyelerinden $150 \mu$ l süspansiyon alınarak, bakteri ve maya gelişimi için Nutrient agar (NA), fungus gelişimi için ise patates dekstroz agar (PDA) besi yeri içeren petri kaplarına aktarılmıştır. Ayrıca, alınan sebze örneklerinden dokuları ezme ve inkübe etme yöntemi kullanılarak analiz çalışmaları yapılmıştır. Bu amaçla, ilk önce sebze örneklerinden $25 \mathrm{~g}$ tartıldıktan sonra stomacher poşetlerinde $225 \mathrm{ml}$ tamponlanmış peptonlu su içerisinde parçalanmıştır. Parçalanan bitki dokuları, $37^{\circ} \mathrm{C}^{\prime}$ de 24 saat süreyle zenginleştirme işlemine tabi tutulmuştur Bu sürenin sonunda daha önce hazırlanıp Petri kaplarına dökülen Nutrient agar ve Kanlı agar besi yerlerine, baget aracılığıyla ekim yapılmıştır. Ekimi yapılan tüm petriler, bakteri gelişimi için $28-30^{\circ} \mathrm{C}$ sıcaklıkta $24-48$ saat, küf gelişimi için ise; $24-25^{\circ} \mathrm{C}$ sicaklıkta $4-5$ gün inkübasyona bırakılmıştır.

\subsection{MALDI-TOF MS cihazı ile mikroorganizma türlerinin tanılanması}

Elde edilen bakteri, maya ve fungus izolatlarının tanı işlemleri, Hatay Mustafa Kemal Üniversitesi Bitki Sağlığı Kliniği Uygulama ve Araştırma Merkezi'nde bulunan MALDI-TOF MS (Matrix Assisted Laser Desorption Ionization- Time of Flight Mass Spectrometry, Bruker Daltonics $\mathrm{GmbH}$, Bremen, Almanya) Mikroorganizma Tanımlama cihazı kullanılarak gerçekleştirilmiş̧iir. Bu aşamada, saf bakteri ve fungus kültürlerinden protein izolasyon işlemi için etanol-formik asit yöntemi kullanılarak ön ekstraksiyon işlemleri yürütülmüştür. Daha sonra Cihazın flex kontrol yazılım programı (Biotyper 3.0; Microflex LT; Bruker Daltonics GmbH, Bremen, Germany) ile elde edilen spektrumlar, Maldi Biotyper Real-Time Classification (RTC) yazılımı ile karşılaştırılarak tanı işlemi sürdürülmüştür. Analiz sonucunda, yüksek olasılıklı tür teşhisi; 2 000-3 000 (yeşil renk), cins düzeyinde ve muhtemel tür düzeyinde teşhis; 1 700-1 999 (sarı renk) arasındaki skala değerleri kullanılarak değerlendirilmiştir (Carolis ve ark., 2012; Chalupová, ve ark., 2014; Kara ve ark., 2017; Uysal ve ark., 2018).

\subsection{Türlerin yoğunluklarının belirlenmesi}

Farklı taze sebze satış noktalarından toplanan örneklerden laboratuvar koşullarında Patates dekstroz agar, Nutrient agar ve Kanlı agar besi yerleri kullanılarak izole edilen fungus ve bakterilerin besi yerlerindeki koloni sayımları yapılmıştır. İzolasyon sırasında her bir bitki türünden 3 petri olacak şekilde ekim yapılmıştır. Bu petriler bakteri gelişimi için $28-30^{\circ} \mathrm{C}$ sıcaklıkta $24-48$ saat, küf gelişimi için ise 4-5 gün süre sonunda her bir petrideki oluşan mikroorganizma türleri sayılarak belirlenmiştir. Elde edilecek tüm veriler, SPSS istatistik programında varyans analizine tabi tutularak ortalamalar, Duncan çoklu karşılaştırma testine göre $(\mathrm{P}>0.05)$ karşılaştırılmıştır.

\section{Bulgular}

\section{1. Örneklerin toplanması ve mikroorganizma türlerinin izolasyonu}

Çalışmanın yürütüldüğü Antakya semt pazarı, Serinyol semt pazarı, Sebze hali ve farklı marketlerin sebze satış reyonu bulunan bölümlerinde 2018 yılının farklı tarihlerinde (ocak-nisan ve ekim aralık) marul, 1spanak, maydanoz, dereotu, nane, roka, lahana, pazı, pırasa şeklinde sebzelerden örnekler alınmıştır. Bu bitkilerden yapılan izolasyonlar sonucunda farklı mikroorganizma türleri besi yerlerinde gelişme göstermiştir. İnkübasyon sonucunda yaklaşık 100 adet bakteri ve maya kolonisi 
Nutrient besi yerinde, 20 adet fungus kolonisi PDA besi yerinde gelişmiştir. Bu koloniler içerisinden farklı türde bakteri ve funguslardan oluşan toplam 65 adet tür saflaştırılmıştır.

\subsection{MALDI-TOF MS tekniği ile mikroorganizma türlerinin tanılanması}

MALDI-TOF MS analizi sonucu mikroorganizmaların dağılımı incelendiğinde, tür düzeyinde 60 adet ile en fazla bakteri türleri tanılanırken, bunu 4 adet fungus ve 1 adet maya izlemiştir. Sebze türleri olarak en fazla marul örneklerinde olmak üzere 14 adet bakteri 2 adet fungus ve 1 adet ise maya türü tanılanmıştır. Bunları ise 1spanak, dereotu, maydanoz ve lahana örnekleri takip etmiştir. En az mikroorganizma türünün roka bitkisinde olduğu tespit edilmiştir. MALDI-TOF MS analizlerinde skor değerleri incelendiğinde ise 49 tür yüksek olasılıklı, 16 tür muhtemel olasılıklı olarak değerlendirilmiştir. (Çizelge 1).

Çizelge 1. Yaprăğ yenen sebze örneklerinde belirlenen mikroorganizmaların MALDI TOF MS sonuçları.

\begin{tabular}{|c|c|c|c|c|c|c|c|c|c|}
\hline Mikroorganizma türü & $\underset{\bar{z}}{\bar{\Xi}}$ & 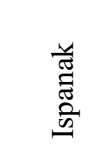 & $\begin{array}{l}\stackrel{\Xi}{\Xi} \\
Z\end{array}$ & 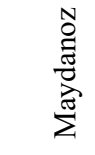 & $\begin{array}{l}\overrightarrow{0} \\
0 \\
0 \\
0 \\
0\end{array}$ & $\frac{\pi}{\ddot{2}}$ & $\begin{array}{l}\mathscr{J} \\
\overparen{\Xi} \\
\Xi\end{array}$ & 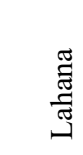 & $\begin{array}{c}\text { MALDI } \\
\text { TOF } \\
\text { MS } \\
\text { değeri }\end{array}$ \\
\hline Pseudomonas gessardi & + & & & & & & & & 2.021 \\
\hline Pseudomonas marginalis & + & & & & & & & & 1.908 \\
\hline Pseudomonas kilonensis & + & & & & & & & & 1.849 \\
\hline Pseudomanas brassicacearum & + & & & & & & & & 2.385 \\
\hline Pseudomanas antarctica & + & & & & & & & & 2.205 \\
\hline Pseudomanas tolaasii & + & & & & & & & & 1.928 \\
\hline Acinobacter johnsonii & + & + & & + & + & + & & + & 2.226 \\
\hline Pantoea agglomerans & + & + & + & & & & & & 2.300 \\
\hline Acinetobacter schindleri & + & & & & & & & & 1.921 \\
\hline Pseudomonas putida & + & & & & & & & & 1.745 \\
\hline Acinetobacter lwoffii & + & & & & & & & & 2.386 \\
\hline Lactobacillus ruminis & + & & & & & & & & 2.094 \\
\hline Bacillus megaterium & + & & & & & & & & 2.145 \\
\hline Acinetobacter radioresistens & + & & & & & & & & 1.900 \\
\hline Alternaria alternata & + & & & & & & & & 2.000 \\
\hline Cladosporium sp. & + & & & & & & & & 1.913 \\
\hline Geotrichum silvicola & + & & & & & & & & 1.760 \\
\hline Lactobacillus delbrueckii ssp lactis & & + & & & + & & & & 1.924 \\
\hline Lactobacillus sakei ssp carnosus & & + & & & + & & & & 1.924 \\
\hline Aeromonas veronii & & + & + & & + & & & & 2.010 \\
\hline Aeromonas bestiarum & & + & & & & & & & 1.998 \\
\hline Klebsiella oxytoca & & + & & & & & & & 2.310 \\
\hline Bacillus cereus & & + & & + & & + & + & & 2.005 \\
\hline Lysinibacillus boronitolerans & & + & & & & & & & 2.098 \\
\hline Lysinibacillus fusiformis & & + & & & & & & & 2.124 \\
\hline Enterobacter cloacae & & + & + & + & & + & + & + & 2.100 \\
\hline Aspergillus niger & & + & & & & & & + & 2.098 \\
\hline Pseudomonas lundensis & & & & + & & & & & 2.124 \\
\hline Exiguobacterium sp & & & & + & & & & & 2.378 \\
\hline Citrobacter braaki & & & & + & & & & & 2.000 \\
\hline Aeromonas caviae & & & & + & & & & & 2.218 \\
\hline Enterobacter asburiae & & & & + & & & & & 2.210 \\
\hline Acinetobacter pittii & & & & + & & & & & 2.100 \\
\hline Acinetobacter bereziniae & & & & & + & & & & 2.010 \\
\hline Pseudomonas cedrina ssp cedrina & & & & & + & & & & 2.021 \\
\hline Aeromonas sobria & & & & & + & & & & 2.312 \\
\hline Enterobacter hormaechei & & & & & & + & & & 2.030 \\
\hline Klebsiella pneumoniae & & & & & & & + & + & 2.098 \\
\hline Escherichia coli & + & & & + & & & & + & 2.120 \\
\hline Salmonella sp. & + & & & + & & & & + & 2.220 \\
\hline Enterococcus casseliflavus & & & & & & & & + & 2.124 \\
\hline Bacillus altitudinis & & & & & & & & + & 2.378 \\
\hline Citrobacter freundii & & & & & & & & + & 1.925 \\
\hline
\end{tabular}


Mikroorganizmaların cins düzeyinde dağılımları incelendiğinde; 9 tür ile Pseudomonas başta gelirken, bunu 5 tür ile Lactobacillus, 4 tür ile Acinetobacter ve 2 tür ile Klebsiella, Citrobacter, Enterobacter, Lysinibacillus, Pantoea ve birer tür ile Bacillus, bir tür Escherichia coli, Exiguobacterium ve Salmonella cinsleri izlemiştir. Bunlar içerisinde insan sağlı̆̆ açısından son derece tehlikeli olarak kabul edilen Escherichia coli, Salmonella sp., Klebsiella pneumoniae, Klebsiella oxytoca, Bacillus cereus, Citrobacter freundii, Enterobacter cloacae, Aeromonas caviae ve Aeromonas sobria türleri başta gelmektedir. Yaprağı yenen sebze türleri açısında incelendiğinde ise insan sağlığı açısından tehlikeli ve yaygın tespit edilen mikroorganizma türleri maydanoz, sspanak ve lahana bitkilerinde bulunmuştur. (Çizelge 1). Çalışma sonucunda elde dilen tüm türler dikkate değer şekilde insan sağlığı açısında tehlike oluşturma potansiyelleri bulunmaktadır.

\subsection{Türlerin yoğunluklarının belirlenmesi}

Mikroorganizma türlerinin koloni yoğunlukları incelendiğinde, en yoğun koloni Pseudomonas ve Acinetobacter cinsine ait türlerde belirlenmiştir. En az koloni yoğunluğu ise funguslarda gözlenmiştir. Bakteriyel mikroorganizmalardan Salmonella sp, Klebsiella pneumoniae, Escherichia coli, Bacillus cereus ve Klebsiella oxytoca türleri insan sağlığı için oldukça tehlikeli türler olması dolayısı ile az miktarda koloni yoğunluklarına sahip olmaları bile dikkate değer düzeyde olarak değerlendirilmiştir. Mikroorganizma türlerinin koloni yoğunlukları sebze türlerine göre incelendiğinde ise, koloni yoğunlukları fazla olan mikroorganizma türleri marul, dereotu, maydanoz, sspanak gibi sebzelerde tespit edilmiştir. (Çizelge 2).

Çizelge 2. Mikroorganizma türlerinin yaprağı yenen sebze türlerine göre koloni yoğunlukları $(\mathrm{cfu} / \mathrm{ml})$

\begin{tabular}{|c|c|c|c|}
\hline No & Mikroorganizma Türleri & Koloni Yoğunlukları (cfu/ml) & Sebzeler Türleri \\
\hline 1 & Pseudomonas gessardi & $43.3 \pm 0.8 \mathrm{i}$ & Marul \\
\hline 2 & Pseudomonas marginalis & $163.3 \pm 3.3 \mathrm{~s}$ & Marul \\
\hline 3 & Pseudomonas syringae & $185.0 \pm 1.0 \mathrm{t}$ & Marul \\
\hline 4 & Pseudomonas synxantha & $23.0 \pm 1.4 \mathrm{e}-\mathrm{g}$ & Marul \\
\hline 5 & Pseudomonas kilonensis & $101.67 \pm 0.8$ op & Marul \\
\hline 6 & Pseudomanas brassicacearum & $35.0 \pm 0.6 \mathrm{~h}$ & Marul \\
\hline 7 & Pseudomanas antarctica & $22.67 \pm 1.4 \mathrm{~d}-\mathrm{g}$ & Marul \\
\hline 8 & Pseudomanas tolaasii & $55.0 \pm 0.6 \mathrm{kl}$ & Marul \\
\hline 9 & Acinobacter johnsonii & $64.67 \pm 2.6 \mathrm{~m}$ & Marul, Roka, Ispanak, Dereotu \\
\hline 10 & Exiguobacterium sp. & $88.0 \pm 0.6 \mathrm{n}$ & Marul \\
\hline 11 & Enterobacter cloacae & $23.0 \pm 1.5 \mathrm{e}-\mathrm{g}$ & Marul, Pırasa, lahana, maydanoz \\
\hline 12 & Janthinobacterium lividum & $7.67 \pm 1.4 \mathrm{a}$ & Marul \\
\hline 13 & Pseudomonas stutzeri & $16.3 \pm 1.4 \mathrm{c}-\mathrm{f}$ & Marul \\
\hline 14 & Pantoea agglomerans & $62.0 \pm 2.71 \mathrm{~m}$ & Marul, Dereotu \\
\hline 15 & Pseudomonas pertucinogena & $35.0 \pm 0.6 \mathrm{~h}$ & Marul \\
\hline 16 & Alternaria alternata & $6.3 \pm 1.4 \mathrm{a}$ & Marul \\
\hline 17 & Cladosporium sp. & $15.67 \pm 1.4 \mathrm{c}-\mathrm{e}$ & Marul \\
\hline 18 & Pseudomonas lundensis & $99.0 \pm 1.0 \mathrm{o}$ & Maydanoz \\
\hline 19 & Citrobacter braaki & $42.67 \pm 0.6 \mathrm{i}$ & Maydanoz \\
\hline 20 & Salmonella sp. & $50.3 \pm 0.6 \mathrm{jk}$ & Lahana, Marul, Maydanoz \\
\hline 21 & Acinetobacter bereziniae & $103.67 \pm 0.8 \mathrm{op}$ & Dereotu \\
\hline 22 & Pseudomonas cedrina ssp cedrina & $66.0 \pm 2.5 \mathrm{~m}$ & Dereotu \\
\hline 23 & Aeromonas sobria & $55.67 \pm 0.6 \mathrm{kl}$ & Dereotu \\
\hline 24 & Lactobacillus delbrueckii ssp lactis & $64.0 \pm 1.4 \mathrm{~m}$ & Ispanak \\
\hline 25 & Lactobacillus sakei ssp carnosus & $66.67 \pm 1.4 \mathrm{~m}$ & Ispanak \\
\hline 26 & Aeromonas veronii & $88.0 \pm 0.6 \mathrm{n}$ & Ispanak, Maydanoz \\
\hline 27 & Colletotrichum gloeosporoides & $5.67 \pm 1.4 \mathrm{a}$ & Marul \\
\hline 28 & Acinetobacter schindleri & $54.0 \pm 0.6 \mathrm{k}$ & Marul \\
\hline 29 & Geotrichum silvicola & $15.0 \pm 1.4 \mathrm{~cd}$ & Marul \\
\hline 30 & Pseudomonas putida & $106.67 \pm 0.8 \mathrm{p}$ & Marul \\
\hline 31 & Acinetobacter lwoffii & $44.67 \pm 1.0 \mathrm{i}$ & Marul \\
\hline 32 & Lactobacillus ruminis & $51.3 \pm 0.6 \mathrm{jk}$ & Marul \\
\hline 33 & Bacillus megaterium & $114.3 \pm 0.8 \mathrm{r}$ & Marul \\
\hline 34 & Acinetobacter radioresistens & $66.67 \pm 2.5 \mathrm{~m}$ & Marul \\
\hline 35 & Klebsiella pneumoniae & $17.67 \pm 1.4 \mathrm{c}-\mathrm{g}$ & Lahana, Pırasa \\
\hline 36 & Escherichia coli & $15.0 \pm 1.4 \mathrm{~cd}$ & Lahana, Marul, maydanoz \\
\hline
\end{tabular}




\section{Tartıșma ve Sonuç}

Taze tüketilen farklı sebze türleri, bitki dokusunun içinde ve yüzeyinde birçok mikroorganizma türünü barındırmaktadır. Bangladeş’te yaygın olarak üretilen ve tüketilen sebzelerde mikrobiyolojik türlerin belirlenmesi amacıyla yürütülen bir araştırma sonucunda hemen hemen tüm sebze örneklerinin bakteri ve mantarlarla aşırı derecede bulaşık olduğu belirlenmiştir. Patojenler arasında Klebsiella spp., Staphylococcus spp. ve Pseudomonas spp. cinslerinin baskın olduğu tespit edilmiştir. Ayrıca, Klebsiella spp., Pseudomonas spp., Bacillus spp., Listeria spp., Escherichia coli ve Vibrio spp. dahil olmak üzere plantasyon toprakları ve gübrelerde önemli ölçüde mikrobiyal artışın olduğunu gözlemişlerdir. Bu çalışmadan elde edilen veriler mikroorganizma türleri bakımından bizim çalışmamızı destekler niteliktedir. (Alam ve ark., 2015).

Bitki patojeni fungal türlerden Aspergillus, Fusarium, Aureobasidium, Alternaria, Bipolaris, Cladosporium, Colletotrichum, Coniothyrium, Corynespora, Curvularia, Exserohilum, Lasiodiplodia, Macrophomina, Microascus, Mycoleptodiscus, Neoscytalidium, Phaeoacremonium, Phoma, Ulocladium, Mucor, Rhizopus ve Rhizomucor'un aynı zamanda insanlarda; sinüs, travma, akciğer enfeksiyonları, felç, kulak iltihabı, göz enfeksiyonları, deri hastalığı, bulaşıcı enfeksiyonlar, kornea iltihabı, beyin uru, karın zarı iltihabı, göz içi iltihabı, sinüzit, deri ve yumuşak doku iltihabı, bağışıklık yetersizliği, lenf doku uru, lösemi, şeker hastalığı gibi hastalıklara neden olduğu bildirilmiştir. Bu çalışmadan elde edilen birkaç fungus türü (Gauthier ve Keller, 2013), çalışmamızda elde edilen Cladosporium, Colletotrichum, Aspergillus, Alternaria fungus türleri ile benzerlik göstermiștir. Klinik örneklerinden izole edilen baskın patojen olan Exserohilum rostratum (telemorf: Setosphaeria rostrata), çayır bitkileri ve seyrek olarak insanları enfekte eden dematiaceous bir fungustur. Bu salgın, fungal patojenlerin hem bitkileri hem de insanları enfekte edebilme potansiyelini vurgulamaktadır. Çoğu patojen, toprak saprofitidir ve Ascomycota ve Mucormycotina şubelerinde yer alan fungusları içerirler.

Bazı firsatçı insan patojenleri, örneğin Burkholderia cepacia kompleksinin üyeleri olan Pseudomonas aeruginosa ve Enterobacter cloacae (Entc), bitki patojenleri olarak kabul edilir ve uzun süredir bitki ile ilişkili olarak kabul edilmektedir (Barak ve Schroeder, 2012). İnsan patojeni bakteriler arasında yer alan Enterococci, Serratia, Enterobacter ve Salmonella, bitkilerde hastalığa neden olma eğilimi oldukça yüksektir (Hasnain ve ark., 2015). Stenotrophomonas'ın (Sharma ve ark., 2014), Burkholderia ve Pantoea'nın farklı bitki patojeni türleri insan patojenleri olarak gelişmektedir (Kirzinger ve ark., 2011). Bu nedenle bitkilerde hastalık yapan patojenlerin insanlarda da hastalık yapabileceği ortaya çıkmış bir durumdur.

Gıda kaynaklı patojenlerden Escherichia coli, taze 1spanak ve marul gibi sebzelerle giderek daha fazla ilişkilendirilmektedir (Wright ve ark., 2013). Taze üretilen bitkilerin bakteriyel kolonizasyonu dış dokuda yüksek seviyelerde oluşabilir, ancak bitki dokusu içerisinde bakteri de tespit edilmiștir.

Dünyanın farklı ülkelerinde bu şekilde elde edilen bakteri, fungus ve maya mikroorganizma türlerinin tanılanmasında kullanılan özellikle hız, güvenilirlik ve ucuz maliyetli olması bakımından önem arz eden MALDİ TOF MS cihazı ile tanımlanması çalışmamızı, diğer ülkelerle paralel çalışma yapılmasına olanak sağlamış ve güvenilirliğini arttırmıştır. Benzer şekilde Hausdorf ve ark. (2013), 1spanak işleme tesislerindeki 1spanak yıkama sularından örnekler almışlar ve alınan su örneklerinden mikrobiyolojik izolasyonlar yapılmış ve elde edilen mikroorganizmalar MALDİ TOF MS cihazı ile tanılanmıştır.

$\mathrm{Bu}$ çalışmada elde edilen bulgularda, Hatay ili açısından taze tüketilen sebzelerin satışının yapıldığı pazar, manav ve marketlerde yaprağı yenen sebze türlerindeki mikrobiyolojik türler ve yoğunlukları belirlenmiştir. Çalışmanın en önemli bilimsel yaygın etkisi, bitkiler ve tarımsal üretim sistemindeki ilgili diğer çevre arasındaki mikroorganizmaların değişimiyle ilgili farkındalık yaratılmıştır. Bununla birlikte insan patojeni ve bitki patojeni mikrobiyal türler arasındaki etkileşime yeni bilimsel bir bakış kazandırılmıştır. Söz konusu türlerin Matrix asisted laser desorption ionizationtime of flight mass spectrometry (MALDİ TOF MS) cihazıyla tanılarının yapılması ile bu alanda çalışan araştırıcılara önemli bir veri sağlamaktadır. Çalışma sonunda elde edilen verilerle, bitkilerdeki insan patojeni fungus ve bakterilerin tür tanıları ortaya konmuş ve bitkilerdeki insan patojeni bu mikroorganizmaların mücadelesine yönelik tarımsal uygulamalar ve sanitasyon işlemleri önerilmektedir. Tarla ya da bahçeden hasat edilen yaprağı yenen sebzelerin pazar ve hallere 
götürülmeden önce temiz çeşme suyu olarak kabul edilebilecek bir suyla yıkanarak topraktan arındırılmalıdır.

\section{Teșekkür}

$\mathrm{Bu}$ çalışma, Hatay Mustafa Kemal Üniversitesi Bilimsel Araştırma Projeleri Komisyon Başkanlığına tarafından 18.M.026 nolu proje kapsamında desteklenmiş ve Hatay Mustafa Kemal Üniversitesi Bitki Sağlığı Kliniği Uygulama ve Araştırma Merkezi laboratuvarlarında yürütülmüştür.

\section{Kaynakça}

Alam, MS., Feroz, F., Rahman, H., Das, K.K., \& Noor, R. (2015). Microbiological Contamination Sources of Freshly Cultivated Vegetables, Nutrition \& Food Science, Vol. 45 No. 4, pp. 646658.

Ayhan, T., Ufuk, B., \& Sine, O.T. (2011). Efficacy of different decontamination treatment on microbial population of leafy vegetables. Journal of Geographic Information and Decision Analysis. 36(1), 9-13.

Barak, J.D., \& Schroeder, B.K. (2012). Interrelationships of food safety and plant pathology: the life cycle of human pathogens on plants. Annual Review of Phytopathology 50, 241-266.

Beuchat, LR. (2002). Ecological factors influencing survival and growth of human pathogens on raw fruits and vegetables. Microbes and Infection. 4, 413-423.

Carolis, E.D., Posteraro, B., Lass-Flo, C., Vella, A., Florio, A. R., Torelli, R., Girmenia, C., Colozza, C., Tortorano, A.M., Sanguinetti M., \& Fadda, G. (2012). Species identification of Aspergillus, Fusarium and Mucorales with direct surface analysis by matrix-assisted laser desorption ionization time-of-flight mass spectrometry. Clinic Microbiology Infect. 18, 475484.

Chalupová, J., Raus, M., Sedlářová, M., \& Šebela, M., (2014). Identification of fungal microorganisms by MALDI-TOF mass spectrometry. Biotechnology Advances, 32, 230-241.

Gauthier, G.M., \& Keller, N.P., (2013). Crossover fungal pathogens: The biology and pathogenesis of fungi capable of crossing kingdoms to infect plants and humans. Fungal Genetics and Biology 61, 146-157.

Hasnain, S., Rehman, Y., \& Mahmood, S. (2015). Cross-Kingdom Pathogenicity across Plants and Human Beings. J. Bacteriol Parasitol, 6, e124.

Hausdorf, L., Mundt K., Winzer, M., Cordes, C., Fröhling, A., Schlüter, O., \& Klocke, M. (2013). Characterization of the cultivable microbial community in a spinach-processing plant using MALDI-TOF MS. Food Microbiology. Food Microbiology, 34, 406-411.

Kara, M., Uysal, A., Soylu, S., Kurt, Ş., \& Soylu, E.M. (2017). Identification of plant-associated microorganisms employing maldi tof mass spectrometry as a rapid detection technique. International Conference on Agriculture, Forest, Food Sciences and Technologies (ICAFOF), 15-17 May, 2017. Nevşehir, p. 1111.

Kasım, M.U. \& Kasım, R. (2016). Taze Kesilmiş Ispanaklarda Farklı Dalga Boyundaki Ultraviyole Işınlarının Hasat Sonrası Kaliteye Etkisi. YYÜ Tar Bil Der, 26(3), 348-359.

Kirzinger, MW., Nadarasah, G., Stavrinides, J. (2011). Insights into crosskingdom plant pathogenic bacteria. Genes, 2, 980-997.

Lund, B.M., Baird-Parker, T.C., \& Gould, G.W. (2000). "The Microbiological Safety and Quality of Food."Volume I. An Aspen Publictions, Maryland,

Mahmood, S., Rehman, Y., \& Hasnain, S. (2015). Cross-Kingdom pathogenicity across plants and human beings. J. Bacteriol Parasitology, 6, 4 .

Mellmann, A., Harmsen, D., Cummings, CA., Zentz, EB., \& Leopold, SR. (2011). Prospective genomic characterization of the german enterohemorrhagic Escherichia coli O104:H4 outbreak by rapid next generation sequencing technology. Microbiology, 105 (6), 1729-1743.

Roberts, T.A., Pitt, J.I., Farkas, J., \& Graw, F.H. (1998). "Microorganisms in Food. Microbial Ecology of Food Commodities." Blackie Academic \& Professional, UK. 
Sengun, I.Y., \& Karapinar, M. (2004). Effectiveness of lemon juice, vinegar and their mixture in the elimination of Salmonella typhimurium on carrots (Daucus carota L.). International Journal of Food Microbiology, 96, 301-305.

Sharma, K., Goss, E. M., Dickstein, E. R., Smith, M. E., Johnson, J. A., Southwick, F. S., \& van Bruggen, A. H. (2014). Exserohilum rostratum: characterization of a cross-kingdom pathogen of plants and humans. PloS one, $9(10)$, e108691.

Sivapalasingam, S., Friedman, C.R., Cohen, L., Tauxe, R.V. (2004). Fresh produce: a growing cause of outbreaks of foodborne illness in the United States, 1973 through 1997. J. Food Prot. 67(10), 2342-2353.

Taşkın, B. (2017). Novel Approaches for Monitoring Viable Pathogenic Microorganisms in Environmental Samples. YYÜ Tar Bil Der, 27(2): 285-291.

Uysal, A., Kurt, Ş., Soylu, E.M., Kara, M., Soylu, S. (2018). Evaluation of the matrix-assisted laser desorption/ionization time-of-flight (MALDI-TOF) mass spectrometry for identification of some plant fungal pathogenic species. International Agricultural Science Congress. 09-12 May Van/Turkey.

Vandekinderen, I., Van Camp, J., Devlieghere, F., Veramme, K., Denon, Q., Ragaert, P., De, \& Meulenaer, B. (2008). Effect of decontamination agents on the microbial population, sensorial quality, and nutrient content of grated carrots (Daucus carota L.). Journal of Agricultural Food Chemistry. 56, 5723-5731.

Wright, K.M., Chapman, S., McGeachy, K., Humphris, S., Campbell, E., Toth, I. K., \& Holden, N. J. (2013). The endophytic lifestyle of Escherichia coli O157:H7: Quantification and internal localization in roots. Phytopathology, 103, 333-340. 